\title{
DYSPHAGIC COMPLAINT EVALUATION ON PATIENTS ON OTORRINOLARYNGOLOGY AMBULATORY AT ONOFRE LOPES UNIVERSITY HOSPITAL
}

\section{AVALIAÇÃO DA QUEIXA DISFÁGICA EM PACIENTES EM AMBULATÓRIA DE OTORRINOLARINGOLOGIA NO HOSPITAL UNIVERSITÁRIO DE ONOFRE LOPES}

Lidiane Maria de Brito Macedo Ferreira1; Daniel de Menezes Cortês Bezerra²; Victor Bruno Fernandes Moreira ${ }^{3}$; Hipólito Virgílio Magalhães Júnior ${ }^{4}$; Cynthia Meira de Almeida Godoy 5 .

1. Adjunct Professor at Otorhinolaryngology on Department of Surgery, Federal University of Rio Grande do Norte (UFRN). Natal-RN. Brazil.

2. Otorhinolaryngologist Physician. Natal-RN. Brazil.

3. Medical Academician of UFRN. Natal-RN. Brazil.

4. Adjunct Professor at Department of Speech-Language and Hearing Sciences, UFRN. Natal-RN. Brazil.

5. Speech therapist on EBSERH (Empresa Brasileira de Serviços Hospitalares), UFRN. Natal-RN. Brazil.

Department of Surgery, Federal University of Rio Grande do Norte (UFRN), Brazil.

Financial Support: None.

Conflict of interest: None.

Mailing address: Department of Surgery, Federal University of Rio Grande do Norte (UFRN), AV. Nilo Peçanha 620, Natal-RN, Brazil. E-mail: orlhuol@gmail.com.

Submitted: april 17; accepted after revision, april 18, 2020.

\section{ABSTRACT}

Purpose: The present study aims to to evaluate, diagnose, treat and refer patients with swallowing disorders, in different age groups, referred to the otorhinolaryngology outpatient clinic of Onofre Lopes University Hospital. Methods: The consultations took place on a frequency of once a week for a period of 12 months. They consisted of speech therapy evaluation, nutritional risk and otorhinolaryngology evaluation, in addition to the Fiberoptic endoscopic evaluation of swallowing. Results: The average age of the patients seen was 62.5 years, and the main comorbidities presented were neurological. Most patients were classified as having mild dysphagia and indicated oral diet with multiple consistencies, but with the need for special preparation or compensation. Approximately $25 \%$ of patients with dysphagic complaints had a risk of malnutrition, a risk that was statistically more significant in those with severe dysphagia (37.5\%) related to those with mild/moderate dysphagia. Among the parameters observed in the 
Dysphagic complaint evaluation on patients on otorrinolaryngology ambulatory at Onofre Lopes University Hospital

Ferreira LMBM, et al

Fiberoptic endoscopic evaluation of swallowing, the presence of salivary stasis, aspiration and penetration were those that showed a statistical association with nutritional risk. Conclusion: The work concludes that nutritional assessment should play a prominent role in the routine of outpatient clinics specialized in dysphagia, reducing the risk of adverse events and improving the general health and quality of life of patients with these complaints.

Key words: Dysphagia, Nasolaryngoscope, Swallowing; Nutritional Status.

\section{RESUMO}

Objetivo: O presente estudo tem como objetivo avaliar, diagnosticar, tratar e encaminhar pacientes com distúrbios da deglutição, em diferentes faixas etárias, encaminhados ao ambulatório de otorrinolaringologia do hospital universitário onofre lopes. Métodos: As consultas foram realizadas uma vez por semana, durante um período de 12 meses. consistiram na avaliação fonoaudiológica, risco nutricional e otorrinolaringologia, além da avaliação endoscópica da fibra óptica por deglutição. Resultados: A idade média dos pacientes atendidos foi de 62,5 anos, e as principais comorbidades apresentadas foram neurológicas. a maioria dos pacientes foi classificada como disfagia leve e indicou dieta oral com múltiplas consistências, mas com necessidade de preparação ou compensação especial. aproximadamente $25 \%$ dos pacientes com queixas disfágicas apresentavam risco de desnutrição, risco estatisticamente mais significativo naqueles com disfagia grave $(37,5 \%)$ relacionados aos com disfagia leve / moderada. dentre os parâmetros observados na avaliação endoscópica da deglutição por fibra óptica, a presença de estase salivar, aspiração e penetração foram os que apresentaram associação estatística com o risco nutricional. Conclusão: $O$ trabalho conclui que a avaliação nutricional deve ter um papel de destaque na rotina de ambulatórios especializados em disfagia, reduzindo o risco de eventos adversos e melhorando a saúde geral e a qualidade de vida dos pacientes com essas queixas.

Descritores: Disfagia, Nasolaringoscópio, Engolir; Estado nutricional.

\section{INTRODUCTION}

According to the World Gastroenterology Organization, "dysphagia" is the sensation of an impediment to the passage of liquid or solid material (or both), when it is swallowed. Such symptom is due to changes in the normal mechanism of food ingestion, and can be consequent to the impairment of any of the phases of swallowing (preparatory, oral, pharyngeal and / or esophageal), a complex physiological process, which involves multiple anatomical structures of the cavity oral, pharynx, larynx and esophagus'. Imbalance in any of these phases can lead to serious pulmonary complications (in case of aspiration of food), malnutrition and dehydration (due to reduced caloric / fluid intake as a protection mechanism or even for not being able to eat an adequate amount of food), in addition to other processes related to high rates of morbidity and mortality. 
Dysphagic complaint evaluation on patients on otorrinolaryngology ambulatory at Onofre Lopes University Hospital

Ferreira LMBM, et al

Anatomically, dysphagia can result from oropharyngeal or esophageal dysfunction, and is therefore classified into these two large groups. Oropharyngeal dysphagia (discharge) is characterized by a disturbance in the transfer of the bolus from the oral cavity to the esophagus, resulting from neurological, muscular or structures abnormalities of the oral cavity, pharynx and upper esophageal sphincter, which can cause functional limitations, sequels and significant changes in general health ${ }^{2}$. The symptoms most frequently referred to in this phase are the difficulty in starting swallowing, choking and feeling of food trapped in the pharynx. Esophageal dysphagia, related to the homonymous phase, is mainly marked by chest pain during swallowing and regurgitation ${ }^{3}$.

Most common diseases that predispose to the onset of dysphagia are neuromuscular diseases such as Parkinson's, Amyotrophic Lateral Sclerosis, motor neuron diseases, strokes, neoplasms of the cervical region, among others ${ }^{4}$. To identify the underlying disease that is leading to dysphagia, as well as instituting appropriate maneuvers and postures at the time of feeding, are important strategies in the management of patients with complaints of choking, difficulty in eating, coughing when swallowing or other complaints related to food.

Through a good multidisciplinary clinical evaluation, performed mainly by otorhinolaryngologist, speech therapists and nutritionists, this diagnosis can be made and appropriate therapy instituted. For a good complementary assessment of the topography and the consequences of dysphagia, it is possible to use the diagnostic resource Fiberoptic endoscopic evaluation of swallowing (FEES), which consists of an endoscopic examination in which swallowing is evaluated under direct vision in the hypopharynx, with administration of colored foods in different consistencies and volumes ${ }^{5}$.

Through this examination, it is possible to identify findings that compromise the proper functioning of swallowing, such as changes in laryngeal sensitivity, presence of food residue in the larynx, presence of food leakage before swallowing, presence of laryngeal penetration or aspiration. Depending on the findings during the examination, together with the patient's clinic and nutritional assessment, specific therapies are instituted: speech therapy, nutritional support, whether in relation to the adequacy of dietary consistencies, or in more extreme cases, with indication of an alternative route to protect the airways and reduce the risk of malnutrition ${ }^{6}$.

In perspective of the demand of patients with swallowing disorders who are referred to the otorhinolaryngology outpatient clinic, and due to the aging of the population as a whole, which is proportionally related to the appearance of these conditions, the need for attention to these patients is notorious and growing patients. The present work was willing to use the space of the swallowing disorders clinic as a place to detect these conditions, as well as classify the degree of dysphagia in these 
Dysphagic complaint evaluation on patients on otorrinolaryngology ambulatory at Onofre Lopes University Hospital

Ferreira LMBM, et al

patients, perform screening for nutritional risk and implement the appropriate therapy for each case.

Thus, the general objective of the work is to associate the degree of dysphagia of patients with related complaints referred to the Otorhinolaryngology outpatient clinic of Onofre Lopes University Hospital with nutritional risk; linked to the objective of tracing the profile of the patient seen at the outpatient clinic, covering sociodemographic and health factors of the patient.

\section{METHODS}

This is a longitudinal study with patients referred to the dysphagia clinic, located at the Otorhinolaryngology Service of Onofre Lopes University Hospital (HUOL), Natal/RN. The sample was collected from all patients seen in the 12-month period in 2019.

Joint Swallowing Assessment Protocol, described by Santoro and colleagues in 20117, the FESS exam according to the protocol described by Langmore and collaborators in $1988^{8}$, Classification of the degree of dysphagia according to Macedo Filho $^{3}$, the Nutritional Risk Assessment according to the Nutritional Risk Screening $2002^{9}$ and the gradation of food levels using the Functional Oral Intake Scale (FOIS) ${ }^{10}$ were used for evaluation.

The otolaryngology, speech therapy and nutrition teams, with identification of predisposing factors, risk factors and worsening situations, carried out the joint assessment. According to the finding of dysphagia, the patient was referred to speech therapy and nutritional monitoring in case of risk of malnutrition.

Patients referring dysphagia, complainnig of gagging with saliva or food; long swallowing; multiple swallows in the same food bolus; reflux of food into the oral or nasal cavity and/or presence of residues in these regions; weight loss due to not eating, resulting from symptoms; sialorrhea after a meal; throat clearing, coughing, hoarseness after a meal; recurrent lung infections; masticatory difficulty and tiredness after eating, were included in this research.

Patients without clinical conditions to perform the Fiberoptic endoscopic evaluation of swallowing, such as terminal patients, disoriented or who do not respond to simple commands, were excluded from the study.

The level of dysphagia was categorized into absence of dysphagia, mild, moderate and severe dysphagia. The other social demographic, health and nutritional risk variables were categorized into dichotomous variables and from there, statistical analysis was performed using the Chi-square and Fisher's Exact tests, for a significance of $5 \%$. 
Dysphagic complaint evaluation on patients on otorrinolaryngology ambulatory at Onofre Lopes University Hospital

Ferreira $L M B M$, et al

As for the norms and regulatory guidelines for research involving human beings governed by Resolution No. 466/2012 - CNS, this study was approved by the Ethical and Research Committee of the Onofre Lopes University Hospital under number 3,027,515.

\section{RESULTS}

Over the twelve months of data collection, a total of 105 patients were treated. Most of the patients evaluated at the HUOL clinic were between 51 - 70 years old $(42.85 \%)$, with a mean age of 62.5 years.

Among the main comorbidities of patients seen at the outpatient clinic, Amyotrophic Lateral Sclerosis (ALS) was the most prevalent (46.29\%), followed by stroke (29.62\%) and Parkinson's (11.11\%).

Regarding the general classification of FOIS (Functional Oral Intake Scale), most patients were from Level 5 (38.8\%), followed by FOIS 7 (21.4\%) and FOIS 6 (13.6\%).

Regarding the classification regarding the degree of dysphagia, $23.3 \%$ had no dysphagia, $41.7 \%$ had mild dysphagia, $14.6 \%$ had moderate dysphagia and $20.4 \%$ had severe dysphagia.

As for the classification of patients assessed in relation to nutritional risk, based on the screening of nutritional risk NRS 2002 (Nutritional Risk Screening), it was observed that approximately $23 \%$ of patients with dysphagic complaints were at risk of malnutrition.

When relating the degree of dysphagia and the FOIS, we observed that most patients with mild or moderate dysphagia had an oral diet indication with multiple consistencies (although with the need for special preparation or compensations) - FOIS 5), while patients with severe dysphagia had contraindications for oral diet (FOIS 1) (Picture 1). 
Dysphagic complaint evaluation on patients on otorrinolaryngology ambulatory at Onofre Lopes University Hospital

Ferreira $L M B M$, et al

25

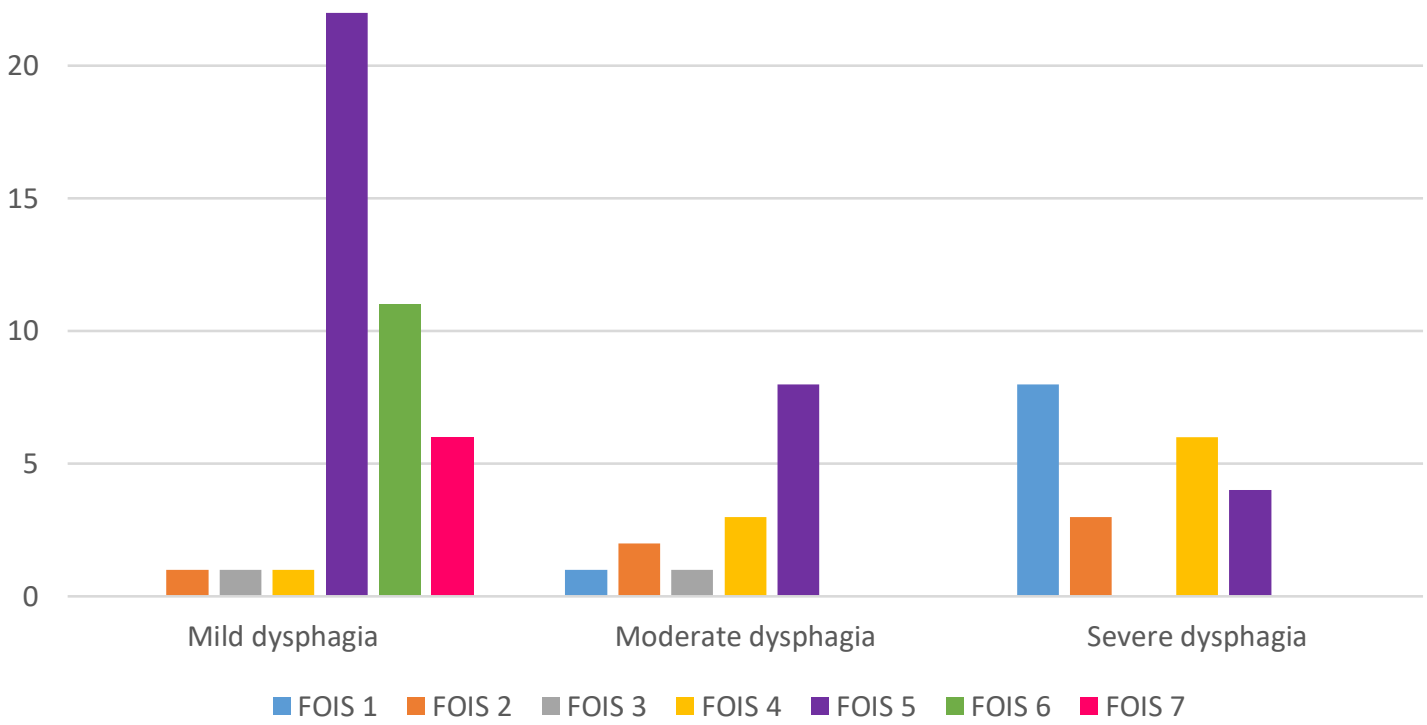

Picture 1 - Relationship between the degree of dysphagia and FOIS in patients at the dysphagia clinic HUOL, Natal / RN, 2019.

Table 1 shows the association between the degree of dysphagia and nutritional risk (increased in patients with severe dysphagia in relation to those of mild to moderate dysphagia), in addition to showing statistical significance between nutritional risk and the presence of salivary stasis, aspiration and laryngeal penetration, observed during the FESS examination.

Table 1 - Associations of nutritional risk with the degrees of dysphagia and the changes observed during the FESS examination. Natal / RN, 2019.

\begin{tabular}{l|c|c|c|c|c}
\hline \multirow{2}{*}{ Variables } & \multicolumn{2}{|c|}{ Nutritional risk } & \multirow{2}{*}{ OR (IC 95\%) } & \multirow{2}{*}{ PR } \\
\cline { 2 - 5 } Mild dysphagia & Yes & No & & & \\
\hline Moderate dysphagia & $6(25 \%)$ & $36(45 \%)$ & 0.080 & & \\
\hline Severe dysphagia & $6(25 \%)$ & $9(11.2 \%)$ & 0.93 & & 2.37 \\
\hline Posterior Oral Escape & $9(37.5 \%)$ & $12(15 \%)$ & 0.016 & $3.4(1.215-9.517)$ & \\
\hline $\begin{array}{l}\text { Insufficient Velopharyngeal } \\
\text { Closure }\end{array}$ & $14(63.6 \%)$ & $54(72 \%)$ & 0.451 & & \\
\hline $\begin{array}{l}\text { Start of Response - Piriform } \\
\text { sinuses and ditches }\end{array}$ & $5(23.8 \%)$ & $21(28 \%)$ & 0.703 & & \\
\hline Multiple swallows & $5(21.7 \%)$ & $12(15 \%)$ & 0.443 & & \\
\hline Salivary stasis & $8(33.3 \%)$ & $10(12.5 \%)$ & 0.018 & $3.5(1.193-10.272)$ & 2.38 \\
\hline Sensibility alteration & $9(40.9 \%)$ & $18(22.5 \%)$ & 0.083 & & \\
\hline Penetration & $14(58.3 \%)$ & $19(24.1 \%)$ & 0.002 & $4.421(1.690-11.565)$ & 2.96 \\
\hline Aspiration & $10(41.7 \%)$ & $11(13.9 \%)$ & 0.003 & $4.416(1.574-12.388)$ & 2.78 \\
\hline Residue & $8(33.3 \%)$ & $36(45 \%)$ & 0.310 & & \\
\hline OR: Odds ratio; & 5.132 & & \\
\hline
\end{tabular}

OR: Odds ratio; $\mathrm{Cl}$ : Confidence Interval; PR: Prevalence Ratio 
Dysphagic complaint evaluation on patients on otorrinolaryngology ambulatory at Onofre Lopes University Hospital

Ferreira LMBM, et al

\section{DISCUSSION}

The average age of patients was 62.5 years, corroborating with data from the general literature on the subject regarding the prevalence of dysphagic complaints, being more common in the elderly population, which is related to a higher risk of complications and leads to increased length of hospital stay and hospital readmission, as well as increased health and mortality costs ${ }^{11,12}$.

The most common comorbidities related to the patients were neurological: patients with Amyotrophic Lateral Sclerosis (ALS) and after strokes, which indicates the role of neurological disorders as one of the main entities involved in the aetiology of dysphagia 4 .

ALS is classified as a progressive degenerative neuromuscular disease related to the alteration of the cells of the motor neurons of the brain stem, medulla, cortical spinal and bulbar pathways, responsible for the control of voluntary movements ${ }^{13}$. Thus, the degeneration of motor neurons leads to muscle alterations causing loss of swallowing ${ }^{14,15}$.

Relating the second entity most associated with dysphagia in the outpatient clinic, post-stroke patients, the fact that stroke is considered one of the main causes of death in Brazil stands out and oropharyngeal dysphagia occurs in about $50 \%$ of patients affected by stroke, which explains the high incidence of this group ${ }^{16}$.

Regarding the general classification of the FOIS, most patients belonged to Level 5 , corresponding to the indication of total oral route with multiple consistencies, but with the need for special preparation or compensation that can minimize complaints dysphagic disorders they refer to ${ }^{10}$. This was because the majority of patients seen were classified as having mild dysphagia, followed by patients without dysphagia, moderate dysphagia and severe dysphagia, in decreasing order of prevalence.

Among those with dysphagia complaints, approximately one in four $(23 \%)$ was at risk of malnutrition, emphasizing the importance of nutritional assessment/multidisciplinary care in this type of outpatient clinic, since changes in the physical consistency of food can cause inadequate food intake. That corroborates the fact that patients with dysphagia have a higher risk of nutritional deficit or are already malnourished ${ }^{17}$.

Finally, when we observe the association between the degree of dysphagia and the nutritional risk presented by each patient, the main objective of our work, we see a clear increase in the percentage of patients with nutritional risk among patients with severe dysphagia (37.5\%) in compared to those with mild / moderate dysphagia, with only severe dysphagia showing statistical significance. This data is confirmed by the FESS findings that showed statistical significance with the nutritional risk (presence of salivary stasis, aspiration and laryngeal penetration), parameters observed in patients with 
Dysphagic complaint evaluation on patients on otorrinolaryngology ambulatory at Onofre Lopes University Hospital

Ferreira $L M B M$, et al

severe dysphagia. This finding reaffirms the need for an alternative route of nutrition in many patients with severe dysphagia ${ }^{18}$.

\section{CONCLUSION}

Dysphagia is a symptom that can be due to several causes and that can have numerous consequences to the individual's general health. Among its possible causes, neurological disorders appear among the main ones, as is the case of Amyotrophic Lateral Sclerosis and patients with sequel of strokes.

On the other hand, among the main health consequences of patients with dysphagic complaints, nutritional risk plays an important role. We also emphasize that this risk increases according to the degree of dysphagia presented.

Thus, there is a clear need for nutritional assessment as part of the routine of any ambulatory specialized in dysphagia, in order to better guide each patient according to the estimated risk presented, increasing the quality of life and minimizing the risk of complications in this context.

\section{REFERENCES}

1. Anderle P, Rech RS, Pasqualeto VM, Goulart BNG, et al. Conhecimento das equipes médicas e de enfermagem sobre o manejo de medicamentos orais no paciente adulto disfágico hospitalizado. Audiol Commun Res. 2018;23:e1933.

2. Carrión S, Cabré M, Monteis R, Roca M, Palomera E, Serra PM, et al. Oropharyngeal dysphagia is a prevalent risk factor for malnutrition in a cohort of older patients admitted with an acute disease to a general hospital. Clin Nutr. 2015; 34: 436-442.

3. Macedo Filho ED. Avaliação endoscópica da deglutição (VED) na abordagem da disfagia orofaríngea. Em: Jacobi JS, Levy DS, Silva LMC. Disfagia - Avaliação e Tratamento. 1a ed. Rio de Janeiro: Editora Revinter; 2003.p.332-42.

4. Cuenca RM, Malafaia DT, Souza GD, Souza LRQ, Motta VP, Lima MRA, et al . Sindrome disfágica. Arq Bras Cir Dig. 2007;20(2):116-8.

5. Gozzer MM, Cola PC, Onofri SMM, Merola BN, Silva RG, et al. Achados videoendoscópicos da deglutição em diferentes consistências de alimento na Esclerose Lateral Amiotrófica. CoDAS. 2020; 32(1):e20180216.

6. Barroqueiro PC, Lopes MKD, Moraes MAS, et al. Critérios fonoaudiológicos para indicação de via alternativa de alimentação em unidade de terapia intensiva em um hospital universitário. Rev CEFAC. 2017;19(2):190-197.

7. Santoro PP, Furia CLB, Forte AP, Lemos EM, Garcia RI, Tavares RA, et al. Avaliação otorrinolaringológica e fonoaudiológica na abordagem da disfagia orofaríngea: proposta de protocolo conjunto. Braz J Otorhinolaryngol. 2011; 77(2):201-13.

8. Langmore SE, Schatz K, Olsen N. Fiberoptic endoscopic examination of swallowing safety: a new procedure. Dysphagia.1988;2:216-9. 
Dysphagic complaint evaluation on patients on otorrinolaryngology ambulatory at Onofre Lopes

9. Barbosa AAO, Vicentini AP, Langa FR, et al. Comparação dos critérios da nrs-2002 com o risco nutricional em pacientes hospitalizados. Ciênc Saúde Coletiva. 2019;24(9):3325-34.

10. Crary MA, Mann GD, Groher ME, et al. Initial psychometric assessment of a functional oral intake scale for dysphagia in stroke patients. Arch Phys Med Rehab. 2005;86(8):1516-20.

11. Izaias ÉM, Dellaroza MSG, Rossaneis MA, Belei RA, et al. Custo e caracterização de infecção hospitalar em idosos. Ciênc Saúde Coletiva. 2014; 19(8):3395-402.

12. Amaro JS, Correia AC, Pereira C, et al. Avaliação do risco de desnutrição num Serviço de Medicina do Hospital Distrital de Santarém (Medicina IV). Acta Port Nutr. 2016;4:06-09.

13. Paik NJ, Kim SJ, Lee HJ, Jeon JY, Lim JY, Han TR, et al. Movement of the hyoid boneand the epiglottis during swallowing in patients with dysphagia from different etiologies. J Electromyogr Kinesiol. 2008;18(2):329-35..

14. Higo R, Tayama N, Nito T, et al. Longitudinal analysis of progression of dysphagia in amyotrophic lateral sclerosis. Auris Nasus Larynx. 2004;31(3):247-54.

15. Gozzer MM, Cola PC, Onofri SMM, Merola BN, Silva RG, et al. Achados videoendoscópicos da deglutição em diferentes consistências de alimento na Esclerose Lateral Amiotrófica. CoDAS. 2020;32(1): e20180216.

16. Schelp AO, Cola PC, Gatto AR, Silva RG, Carvalho LR, et al. Incidência de disfagia orofaríngea após acidente vascular encefálico em hospital público de referência. Arq Neuro-Psiquiatr. 2004;62(2b):503-6.

17. Bassi D, Furkim ASCA, Coelho MSPH, Rolim MRP, Alencar MLA, et al. Identificação de grupos de risco para disfagia orofaríngea em pacientes internados em um hospital universitário. CoDAS. 2014; 26(1): 17-27.

18. Carvalho AMR, Oliveira DC, Neto JEH, Martins BCC, Vieira VMSF, Silva LIMM, et al. Análise da prescrição de pacientes utilizando sonda enteral em um hospital universitário do Ceará. R Bras Farm Hosp Serv Saúde. 2010;1(1):17-22. 